\title{
HORIZONTAL STRAINS OVER THE LENGTH OF SINGLE SECTION OF OBSERVATION LINE - PROBLEM ANALYSIS
}

\author{
${ }^{1}$ AGH University of Science and Technology, Faculty of Mining Surveying and Environmental Engineering, Krakow, Poland \\ Pawel.Sopata@agh.edu.pl
}

Keywords: horizontal strains, surface deformations, buildings hazard

\begin{abstract}
The problem of studying values of horizontal strains occurring over the length of single sides of observation line has been raised in the article. A particular attention has been paid to relevance of this issue in the aspect of assessments made with respect to hazards of mining areas. Lack of knowledge of factually occurring values of horizontal strains in the aspect of commonly determined mean index values (assigned for the entire side length) in case of substantial mutual differences may result in low credibility of prepared assessments. It may also explain arising damages to facilities on lands of thus defined category of a mining area.
\end{abstract}

\section{ODKSZTALCENIA POZIOME NA DLUGOŚCI POJEDYNCZYCH BOKÓW LINII OBSERWACYJNEJ - ANALIZA PROBLEMU}

Słowa kluczowe: odkształcenie poziome, deformacje powierzchni, zagrożenie budynków

\begin{abstract}
Abstrakt
W artykule poruszono problem badania wartości odkształceń poziomych występujących na długości pojedynczych boków linii obserwacyjnych. Zwrócono szczególną uwagę na istotność tego zagadnienia w aspekcie wykonywanych dziś ocen zagrożenia terenów górniczych. Brak znajomości faktycznie występujących wartości odkształceń poziomych w aspekcie wyznaczanych powszechnie średnich wartości wskaźnika (przypisywanych dla całej długości boku) w przypadku ich dużych wzajemnych różnic może być przyczyną małej wiarygodności sporządzanych ocen. Może to wyjaśniać również występowanie uszkodzeń obiektów na terenach o ustalonej w ten sposób kategorii terenu górniczego.
\end{abstract}

\section{INTRODUCTION}

Commonly applied surveying methods of observation lines enable determination of deformation indicators, averaged values of which are ascribed to particular lengths of line sides. At the length of a given side (typically $24 \mathrm{~m}$ or $48 \mathrm{~m}$ ) they represent thus a certain constant level. However, distribution of indicator values at such length is not linear, and all the more uniform. Acquaintance with factually occurring fluctuations of horizontal strain values within the limits of sides is relevant from the perspective of prepared assessments of hazards of mining terrains. Currently, such assessments are based on mean values, taking into account the possibility of so-called random dispersion. These statistics have also been developed based on mean indicator values, determined out of measurements of standard lengths of the observation line sides (Budryk and Knothe, 1956). Lack of knowledge regarding the scope of actual values of indicators at the site of conduction 
of surveys (location of protected facilities) might negatively influence the credibility of these assessments. Thereby, it translates into the lack of familiarity with factual hazards, to which facilities subjected to protection might be exposed.

\section{STATE OF THE ART}

One of the major hazards to buildings and technical infrastructure on the terrain surface arises from horizontal strains (NCB, 1975; Ostrowski et al., 2001; Peng, 1992). Overview of literature in taken up subject indicates that since the end of 1960s studies have been carried out in the scope of impact of length of surveying bases upon the appointed values of this deformation indicator (Batkiewicz, 1971; Siembab, 1969; Szpetkowski, 1969). This research meant mostly theoretical considerations based on experience arising at first from surveys done in the terrain (Milewski, 1969; Szpetkowski, 1969), and later on various equivalent models created on this basis (Batkiewicz, 1971; Klein, 1975, 1981, 1984; Niemiec, 2012; Zych, 1991, 1993, $1998,1999,2010)$. However, they were primarily oriented to optimization of surveying bases lengths in observation lines (Milewski, 1975; Pielok, 1982; Peng and Geng, 1982; Sroka, 1990), proving the dependence of specified horizontal strain values on length of surveying bases, based on which they were assigned (Milewski, 1969, 1975; Stoch et al., 2014; Szpetkowski, 1969). However, most researchers did not apply surveying bases shorter than $6 \mathrm{~m}$. Classic length measurement made on short bases (up to a few meters) burdens the value of determined indicator with too heavy bias.

On the other hand, too long sides of observation line (within the scope of several dozen meters) do not allow a correct interpretation of findings due to unfavorable averaging of indicator at these lengths (Hejmanowski and Kwinta, 2007; Ostrowski, 1982; Popiołek and Ostrowski, 1981; Pielok, 2005; Sopata et al., 2016). It creates serious problems to proper assessment of factual threat to terrain surface (and facilities) resulting from the carried out mine exploitation.

Even greater problems occur in case of forecasting the influences of designed exploitation. Several factors have an impact on accuracy of this type of hazard assessments. The most important of them are: an applied model of deformation process, adequacy of this model to real conditions and the course of process as well as the completeness and precision of assignment of model parameter values (Kowalski, 2007). A fundamental condition of reliability of the terrain surface deformation forecast is an appropriate description of rock mass as an environment, in which this process takes place.

It is not easy, since rock massif is characterized by high degree of the complexity of geological structure, both in terms of structural and mechanical properties. Formulated models of deformation process thus far reduce a rock massif description to one or at most to three parameters (Knothe, 1953). In consequence, characterization of rock mass becomes simplified to a large extent, and in case of one parameter all the possible properties, affecting the deformation process and its aftermath are averaged.

Currently, Knothe's model (Knothe, 1984), also called Knothe-Budryk's theory is mainly used in Poland for forecasting impacts of underground mining operation. The model allows us to determine, e.g. horizontal strains of terrain surface. As it was stated before, forecast of strain values have a decisive effect on assessment of the the hazard to buildings due to deformations, which will occur in their area during the process and upon the completion of designed mining of deposit. As findings of many years of research in horizontal strain values show, forecasts according to Knothe's model are burdened with uncertainty in range of $25 \div 30 \%$ (Kowalski, 2007; Popiołek, 1976; Popiołek et al., 1997; Stoch, 2005). It is worth to emphasize that it refers to averaged indicator values defined based on measurements of standard lengths of sides of observation lines ${ }^{1}$. This uncertainty results from the fact that the discussed model does not allow the consideration of all relevant conditions of deformation process, particularly related to geomechanical properties of the rock mass. Characterization of these properties is reflected in model by only one parameter

\footnotetext{
${ }^{1}$ It results from many years of observations that very often observed (along observation lines) deformation indicators prove irregularities indicating existence of factors other than included in the model. Usually, these factors are called random factors. They are characterized, e.g. by so-called random scatter coefficient. This measure is defined relying on measured values of deformation indicator on sides of observation lines of lengths within a few dozen meters (typically $24 \mathrm{~m}$ or $48 \mathrm{~m}$ ). So appointed deformation indicator represents then a certain averaged value, ascribed to entire length of the side (constant value at entire length of the side). Thus, the coefficient of variation does not allow for factual indicator values of deformation, which occur within limits of each of the sides of the observation line.
} 
$\operatorname{tg} \beta$ suggesting that deforming rock mass is homogeneous and continuous (Knothe, 1984). Such premise is a great simplification of real rock mass structure due to notable diversification of its mechanical and structural properties. As hitherto carried out research showed, the average (at present commonly determined) indicator value for side of $24 \mathrm{~m}$ length remarkably deviates from factually occurring values within such side (Sopata et al., 2016).

\section{EXTENT OF RESEARCH}

Within frameworks of the subject undertaken in the article, the works concerning studies of distribution of horizontal strains within sides of standard lengths ( $24 \mathrm{~m}$ and $48 \mathrm{~m}$ ) have begun in recent years (Sopata et al., 2016). For this purpose a special observation network has been designed and a proper methodology of observations has been developed (also related to making a special measuring instrument). It enables us to acquire necessary data, which after a proper elaboration allow us to carry out the said analyses.

The surveys have been conducted in five regions of the Upper Silesia. An observation network in each area was comprised of set of two standard side lengths of observation line $(24 \mathrm{~m})$ concentrated with additional surveying points at distances of $1 \mathrm{~m}$. The measurement of 1-meter section lengths (using an aforementioned instrument) allows to determine a value of horizontal strain directly at each meter of each side with an accuracy higher than $\pm 0,1 \mathrm{~mm} / \mathrm{m}$. In addition, sections of $6 \mathrm{~m}, 12 \mathrm{~m}, 18 \mathrm{~m}, 24 \mathrm{~m}$ and $48 \mathrm{~m}$ lengths are subject to measurements with the application of the optoelectronic distance meter. Measurements done based on network in each of the study areas cover between a few dozen up to several dozen series of observations performed in the period of a few months (time interval between series equals 1-2 weeks). Frequency and period of taking measurement are adjusted to intensity of underground mining excavation.

Due to extensive subject, details concerning employed research methodology as well as measuring equipment will be described in other articles.

\section{RESULTS}

The results acquired during the field surveys allow us to study the distribution of deformation indicators (especially horizontal strains) in terms of discrepancy of values specified based on 1-meter bases off determined averaged value, arising from classic surveying (particularly determined based on measurement of length side of $24 \mathrm{~m}$ ). Initially, analyses of these findings point to the possibility of occurrence of substantially enlarged values of studied deformation indicator within the limits of line sides, compared to the mean value determined in this same place. It appears that average horizontal strains determined based on $24 \mathrm{~m}$ and $48 \mathrm{~m}$ bases may be even a few times smaller than factually (locally) occurring values, ascertained within these sections. Within one of several examples of observations of distributions of relevant indicators it may be given that strain value determined based on surveys of base of $24 \mathrm{~m}$ length amounted to less than $\varepsilon=+2 \mathrm{~mm} / \mathrm{m}$ (average value), whereas strains on one of sections of $1 \mathrm{~m}$ length inside this base exceeded the level of $\varepsilon=+8 \mathrm{~mm} / \mathrm{m}$. In an extreme case, the value of horizontal strain based on survey of base of $24 \mathrm{~m}$ length reached about $\varepsilon=+4 \mathrm{~mm} / \mathrm{m}$ (mean value), whereas the value of $\varepsilon=+55 \mathrm{~mm} / \mathrm{m}$ was recorded on one of 1 -metre sections, at the same time discontinuous deformations were not observed. Thus, horizontal strains designated on short bases (e.g. $1 \mathrm{~m}$ ), significantly exceeding (at least a few times) mean values, attributed to sides of standard length (e.g. $24 \mathrm{~m}$ ) determined based on distance surveys of these sections, may be recognized as "excessive".

The horizontal strain values obtained on this stage of research indicate the significance of the considered topic. For this reason, they should be analysed. The results of this analysis will be the content of further publications. At present, they are in the course of being prepared.

Occurrence of "excessive" (deviating not only from those determined based on survey, but also based on forecast) indicators values, substantially exceeding a currently assumed level of random dispersion, may be helpful in explanation of many noted cases of damage to facilities in areas of predicted hazard to terrain surface, particularly in places where category of a mining area is in the range of the endurance of facilities.

In this respect, a specific case of damage to structure of newly erected single-family building (Niedojadło et al., 2016) may be proposed as a result of excessive compressions of area surface, which occurred on a relatively small area.

In spite of undertaking appropriate margins for the forecasts of mining impacts during construction, the building was not suitable for further use and was de- 
molished. The fact that a few neighboring buildings did not suffer more serious damage can suggest occurrence of "excessive" values in this site.

\section{SUMMARY}

Preliminary research findings presented in the article, in the light of current conditions of mining may lead to better and deeper recognition of currently occurring phenomenon of deformation, which shows a high irregularity. They provide information of factually occurring values of deformation indicators in the area (particularly horizontal strains), based on which more accurate assessments of hazard to terrain surface may be made, characterized by greater credibility. Thereby, they also give rise to a serious premise that a real hazard results from a local extreme of strains, and not from their average value determined for the entire measurement section of standard length within a few dozen meters.

The conducted research creates foundations for developing a proper and improved methodology of forecasting effects of deformation process, both in case of already existing and newly raised facilities, where the currently carried out forecast of impacts (by Knothe's theory), in many cases, does not reflect the actual hazard of mining operations.

Thus the analysis of the subject matter presented in the article indicates the current state and the need for further research oriented towards more accurate determination of indicator distribution and development of properly adjusted surveying methodology.

This subject is currently realised. In the immediate future detailed results of the survey in the respective research area and their analysis will be presented. They will be conducted in the aspect of terrain and infrastructure hazard.

\section{ACKNOWLEDGMENTS}

This work was supported by statutory research funds from the Faculty of Mining Surveying and Environmental Engineering AGH-UST no. 16.16.150.545 (Department of Mining Areas Protection, Geoinformatics and Mine Surveying).

\section{REFERENCES}

Batkiewicz W. (1971): Standard deviations of post-mining deformation of the rock mass. PWN, Geodesy, 10, Kraków (in Polish).
Budryk W., Knothe S. (1956): The rules for classifying the area of the Upper Silesian industrial district due to the possibility of building them. Technical protection of construction investments in mining areas. Komitet dla Spraw Górnośląskiego Okręgu Przemysłowego. Komisja Mechaniki Górotworu PAN, Bulletin no. 4, Warszawa (in Polish).

Hejmanowski R., Kwinta A. (2007): Horizontal strain and length of measurement base. Scientific Papers of Silesian University of Technology. Series: Mining, no. 278 (1752), 131-140 (in Polish).

Klein G. (1975): The length of the measuring base and the size of the deformation fluctuations in the bulk material. Zeszyty Problemowe Górnictwa, 13, 1, Warszawa (in Polish).

Klein G. (1981): Determination of deformations in the rock mass, taking into account their random character. Archive of Mining Sciences, 26, 4 (in Polish).

Klein G. (1984): Remarks on the influence of the length of the measuring base on the estimators of the variance of deformation fluctuations. Archive of Mining Sciences, 29, 1, 57-64 (in Polish).

Knothe S. (1984): Forecasting the impact of mining operations. Śląsk publishing house, Katowice (in Polish).

Knothe S. (1953): The equation of the profile of the finally developed subsidence basin. Archives of mining and metallurgy, 1,1 (in Polish).

Kowalski, A. (2007): Transient mining surface deformations in the prediction accuracy aspect. Central Mining Institute, Pap No. 871, Katowice (in Polish).

Milewski M. (1969): On the interpretation of research results carried out using geodetic methods in areas affected by mining. Materials of $1^{\text {st }}$ National Symposium on: Protection of surface against mining damage, Katowice (in Polish).

Milewski M. (1975): Measurements of deformations in mining exploitation areas carried out in protective pillars. Conferene papers N.T. Stowarzyszenia Inżynierów i Techników Górnictwa, Katowice (in Polish).

National Coal Board (1975): Subsidence Engineer's Handbook, Mining Department, London.

Niedojadło Z., Piwowarski W., Mościcki W., Sopata P., Stoch T., Bania G., Ćwiklik M. (2016): The impact of local surface geological structure on ground deformation under the conditions of underground mining exploitation. Mining Review, 1, 18-26 (in Polish).

Niemiec T. (2012): Prediction of mining exploitation impacts considering the front velocity and randomness of the process. Mining Review, 8, 192-203 (in Polish).

Ostrowski J. (1982): Post-mining surface displacement in the light of linear models of rock mass deformation. Doctoral dissertation, AGH-UST, Kraków (unpublished, in Polish).

Ostrowski J., et al. (2001): Environmental protection in mining areas. Publishing house of Mineral and Energy Economy Research Institute Polish Academy of Science, Kraków (in Polish).

Peng S.S. (1992): Surface Subsidence Engineering. Society of Mining Engineering, New York.

Peng S.S., Geng D.Y. (1982): Methods of Predicting the Subsidence Factors, Angle of Draw and Angle of Critical De- 
formation. Proceedings State of the Art of Ground Control in Longwall Mining and Mining Subsidence, SME-AIME, Littleton.

Pielok J. (1982): Über die zeitliche Wiederholung von Deformationsmesungen im Bergsenkungsgebietund die Auswahl der Basisgrößen. Das Markscheidewesen, 89, 3, 105-107.

Pielok J. (2005): Determination of surface tensor of deformations in mining areas based on geodetic measurements. Uczelniane Wydawnictwa Naukowo-Dydaktyczne AGH, Kraków (in Polish).

Popiołek E. (1976): Dispersion of statistical horizontal deformations in the light of geodetic observations of the effects of mining exploitation. Scientific Papers of AGH-UST, Geodesy no. 44, Kraków (in Polish).

Popiołek E., Ostrowski J. (1981): An attempt to determine the main reasons for the discrepancy of forecasted post-mining observations of deformation indicators. Mining Areas Protection, 58 (in Polish).

Popiołek E., Ostrowski J., Stoch T. (1997): Random scattering of post-mining indicators of surface area deformation in the present conditions of mining exploitation in Poland. Conference papers of IV Dni Miernictwa Górniczego i Ochrony Terenów Górniczych, Rytro (in Polish).

Siembab J. (1969): Some problems of establishing rational establishment of observation lines to study the impact of mining operations on the surface. Materials of $1^{\text {st }}$ National Symposium on: Protection of surface against mining damage, Katowice (in Polish).

Sopata P., Wójcik A., Mrocheń D. (2016): Length changes within the single side of the observation line. In: Jaśkowski, W. (Eds): Mining Surveying and Protection of Mining Areas in the Current Conditions for Extraction of Mineral Resources in Poland, Kraków (in Polish).

Sroka A. (1990): Richtlinien für Anlage von Messlinien und zur Bestimung des Zeitabstandes zwischen der Messepochen bei Senkumgs und Längenmessungen im Ruhrrevier, Interne Ausarbeitung der Bergbau Niederhein AG, Duisburg.
Stoch T. (2005): Influence of geological and mining conditions of deposit exploitation on the randomness of the process of displacement and deformation of the terrain surface. Doctoral dissertation, AGH-UST, Kraków (unpublished, in Polish).

Stoch T., Ostrowski J., Niedojadło Z., Sopata P., Skobel P. (2014): Observed vs. modelled distributions of horizontal deformations in measurement rosettes. Mining Review 8, 165-170 (in Polish).

Szpetkowski S. (1972): Formation of horizontal deformation appropriate on the basis of observations from several area mining basins. Works of the Mining and Geodetic Commission, Series: Mining, 11 (in Polish).

Szpetkowski S. (1969): Determination of the length of the sides of the observation lines for surface deformation tests. Mining Areas Protection, 9 (in Polish).

Zych J. (1999): Horizontal deformation of the area, their forecast and measurement. Scientific Works of Central Mining Institute, Series: Conferences, no. 30, V Dni Miernictwa Górniczego i Ochrony Terenów Górniczych, Katowice (in Polish).

Zych J. (1991): The influence of the distance of observation points on the approximation error of the measured deformation indicators. Scientific papers of AGH-UST, Series: environmental science and technology, 43, Kraków (in Polish).

Zych J. (1993): The influence of distance of points in observation lines on the size and distribution of the measured deformation indicators. Conference papers of II Dni Miernictwa Górniczego i Ochrony Terenów Górniczych, Ustroń-Jaszowiec, 177-186 (in Polish).

Zych J. (1998): The influence of distance of points in observation lines on the value calculated from horizontal deformation measurements. Archive of Mnining Sciences, 43, 2 (in Polish).

Zych J. (2010): The influence of distance of points in observation lines on the value calculated from horizontal deformation measurements. Mining and Geology, 5, 2 (in Polish). 